Применение подкормки микробиологическими препаратами «Азотовит» и «Фосфатовит» на посевах гороха

\author{
Н. Н. Михайлова ${ }^{\circledR}$, Л. В. Елисеева ${ }^{1}$, И. П. Елисеев ${ }^{1}$ \\ ${ }_{1}^{1}$ Чувашский государственный аграрный университет, Чебоксары, Россия \\ E-mail: cool.gordeeva@list.ru
}

Аннотация. В современном мире особое внимание уделяется получению экологически чистой продукции: применение ядохимикатов сильно сказывается не только на окружающей среде, но и на здоровье человека. В связи с этим растет производство альтернативы ядохимикатам - биопрепаратов. Использование микробиологических удобрений улучшает плодородие почвы, повышает урожайность культуры. Цель работы состоит в изучении влияния подкормок микробиологическими удобрениями «Азотовит» и «Фосфатовит» на продуктивность сортов гороха. Научная новизна работы заключается в том, что впервые в условиях Чувашской Республики в УНПЦ «Студенческий» на светло-серой лесной почве было изучения влияния микробиологических удобрений на продуктивность сортов гороха. Методы учета и наблюдения проводили по общепринятой методике полевого опыта. Результаты. Исследование, проведенное в 2018-2019 гг. в условиях Чувашской Республики, выявило положительный эффект от подкормок микробиологическими удобрениями на сортах гороха Дударь и Спартак. Было отмечено изменение высоты растений, повышение их сохранности, увеличение показателей структуры урожая и урожайности сортов гороха. Так, подкормка «Азотовитом» гороха сорта Спартак увеличила высоту растений на 4 \%, при подкормке «Фосфатовитом» изменений по данному показателю не наблюдалось. Применение «Азотовита» на сорте Дударь увеличило сохранность растений на 5,3 \%, а «Фосфатовита» - на 2,6 \%. Анализ элементов структуры урожая показал, что подкормки микробиологическими удобрениями увеличили количество бобов с растения, семян в одном бобе, а также массу семян с растения и 1000 штук. Существенное увеличение урожайности выявлено в вариантах с подкормками. Так, использование «Азотовита» на посевах сорта Дударь способствовало увеличению урожайности на 37 \%, а «Фосфатовита» - на 12,5 \%; в вариантах с сортом Спартак подкормка «Азотовитом» повысила урожайность на 12,0 \%, подкормка «Фосфатовитом» - на 9,1 \%.

Ключевые слова: горох, микробиологические удобрения, Азотовит, Фосфатовит, продуктивность, подкормка, структура урожая, урожайность.

Для цитирования: Михайлова Н. Н., Елисеева Л. В., Елисеев И. П. Применение подкормки микробиологическими препаратами «Азотовит» и «Фосфатовит» на посевах гороха // Аграрный вестник Урала. 2022. № 02 (217). C. 12-22. DOI: 10.32417/1997-4868-2022-217-02-12-22.

Дата поступления статьи: 13.07.2021, дата рецензирования: 03.09.2021, дата принятия: 30.09.2021.

Постановка проблемы (Introduction)

В последнее время развивается биологизация земледелия. В отличие от традиционного ведения сельского хозяйства это направление считается экологичным. Данный подход к сельскому хозяйству снижает пестицидную нагрузку, продукция становится безопасной $[1$, с. 45$]$. Биологическое земледелие включает в себя применение биологических удобрений, фунгицидов, инсектицидов, регуляторов роста и т. д. [2, с. 422]. Известно, что пестициды отрицательно влияют на экосистему [3, с. 1]. Поэтому развитие сельского хозяйства в направлении биологического земледелия поможет сохранить биоразнообразие нашей планеты и получить 12 экологически чистую продукцию. На сегодняшний день разрабатывается альтернатива минеральным удобрениям, например, можно отнести к таковым микробиологические удобрения. Установлено, что применение биологических препаратов эффективно в борьбе с болезнями, вредителями, способствует сохранению плодородия почвы. Микробиологические удобрения повышают урожайность сельскохозяйственных культур, содержание ценных веществ в получаемой продукции [4, с. 37], [5. с. 43]. В сравнении с минеральными удобрениями применение микробиологических удобрений экономически оправдано, так как они отличаются своей дешевизной и невысокими нормами внесения [6, с. 14]. 
В опытах по изучению влияния биопрепаратов на основе живых бактерий при возделывании гороха отмечено, что увеличиваются полевая всхожесть семян, длина и масса всей вегетативной части растения [7, c. 240]. Наиболее изученным из удобрений, в состав которых входят живые бактерии, является «Ризоторфин». Бактерии рода Phizobium находятся в симбиозе с бобовыми растениями, усваивают атмосферный азот и при этом снабжают растения необходимым биологически связанным азотом. В результате биопрепараты на основе этих бактерий способствуют ростостимулирующей активности культур [8, с. 57]. Изучение влияния «Ризоторфина» на нуте и горохе показало, что данный препарат сокращает время фенологических фаз, длину вегетационного периода и влияет на урожайность этих двух культур [9, с. 73]. Способы и кратность обработок композициями микроудобрений на горохе позволяют увеличить полевую всхожесть семян, способствуют выравненности посевов, формированию большего количества клубеньков, повышают массу 1000 семян, количество бобов на одном растении и среднее количество семян в каждом бобе [10, с. 299]. Применение «Ризоторфина» на зерновых бобовых культурах изучено достаточно полно и в различных регионах страны. Однако в настоящее время ассортимент удобрений, содержащих живые бактерии, постоянно расширяется, что требует изучения различных вариантов их применения на наиболее распространенных зерновых бобовых культурах.

Из всего ассортимента микробиологических удобрений выделяются «Азотовит» и «Фосфатовит». Проведено достаточно исследований по влиянию этих препаратов на зерновые и зернобобовые культуры. Их использование в баковых смесях с пестицидами при протравливании, листовой подкормке способно обеспечить высокие энергоэкономические показатели технологии возделывании зерновых культур [11]. Положительный эффект наблюдался при совместном применении «Азотовита» и «Фосфатовита» с минеральными удобрениями [12, с. 22]. В частности, на бобовых культурах установлено, что обработка семян микробиологическими препаратами «Азотовит» и «Фосфатовит» обеспечивает интенсивный рост и развитие растений на ранних стадиях развития, что дает ускоренное формирование семядолей и настоящих листьев, активируют рост клубеньковых бактерий, увеличивает содержание белка и урожайность семян [13, с. 365]. Внекорневая обработка данными удобрениями стимулирует рост и развитие, активизирует симбиотическую и фотосинтетическую деятельность растений, повышает продуктивность и качество получаемой продукции [14, с. 43].

Микробиологические препараты «Азотовит»и и «Фосфатовит» позволяют обеспечивать растения в доступной форме азотом, фосфором, калием, повышают усвояемость питательных веществ, увеличивают урожай сельскохозяйственных культур, угнетают патогенную микрофлору, оздоравливают и восстанавливают плодородие почвы. Инокуляция семян бактериальными препаратами позволяет активизировать прорастание, рост и развитие растений, повышает устойчивость к стрессовым факторам среды, обеспечивает высокую продуктивность культуры. Свободноживущие почвенные бактерии Azotobacter chroococcum и Bacillus mucilaginosus, обеспечивающие процессы разложения органических веществ и минерализацию, являются основой в производстве данных препаратов. Уникальность «Азотовита» состоит в том, что бактерии, входящие в его состав, фиксируют из воздуха от 20 до 100 кг/га молекулярного азота за вегетационный период, переводят его в доступную для растений аммонийную и нитратную формы. А бактерии в составе препарата «Фосфатовит» участвуют в потреблении растениями фосфора и калия, переводя их из недоступных форм в доступную [15, с. 56]. Все вышесказанное указывает на необходимость изучения данных микробиологических препаратов в конкретных условиях Чувашской Республики как достаточно экономичный прием повышения продуктивности зерновых бобовых культур и качества зерна, в частности гороха.

Методология и методы исследования (Methods)

Цель исследований состояла в изучении влияния корневых подкормок микробиологическими удобрениями «Азотовит» и «Фосфатовит» на продуктивность сортов гороха.

Задачи:

1) установить влияние корневых подкормок микробиологическими удобрениями на рост, развитие и сохранность растений к уборке;

2) выявить зависимость элементов структуры урожая сортов гороха от применения микробиологических удобрений;

3) определить влияние корневых подкормок «Азотовитом» и «Фосфатовитом» на урожайность сортов гороха и качественные показатели полученного зерна.

Опыты были заложены в УНПЦ «Студенческий» Чувашского ГАУ в 2018-2019 гг. В качестве объектов исследований были выбраны сорта гороха разных морфотипов, рекомендованные для возделывания в условиях Чувашской Республики: Дударь (безлисточковый) и Спартак (хамелеон).

Территория УНПЦ «Студенческий» Чувашского ГАУ расположена в северной части Чувашской Республики. Почва опытного участка серая лесная, образована на лессовидном суглинке и глине, слабокислая и близкая к нейтральной $(\mathrm{pH}=5,2)$. Обеспеченность гумусом низкая (2,76 \%), фосфором - повышенная (19,5 мг / 100 г), калием - сред- 
|| няя (17,8 мг / 100 г). Климат Чувашской Республики умеренно континентальный, характеризирующийся холодной морозной зимой и жарким летом. Территория опытного участка относится к зоне с неустойчивым увлажнением, годы и сезоны с избыточным увлажнением нередко сменяются длительными бездождевыми периодами и засушливыми годами. За год в среднем выпадает 470 мм атмосферных осадков, испаряемость - 500 мм. Республика находится под преобладающим воздействием воздушных масс умеренных широт, перемещающихся с запада.

Обработка почвы строилась исходя их рекомендаций для региона при возделывании гороха и включала в себя лущение стерни, зяблевую вспашку, предпосевную культивацию с боронованием. В течение вегетационного периода проводили фенологические наблюдения по фазам роста и развития, определяли влияние микробиологических препаратов на сохранность растений гороха и устойчивость их к полеганию, учет урожая и определение элементов его структуры проводили по методике Госу- дарственного сортоиспытания, статистическую обработку полученных данных - по методике Доспехова [17]. Качественный анализ семян гороха определяли в Исследовательском лабораторном центре Чувашского ГАУ по следующим методикам: сырой протеин - по ГОСТ 32044.1-2012; сырой жир - по ГОСТ 13496.15-2016; клетчатка - по ГОСТ 31675 2012; сырая зола - по ГОСТ 32933-2014; азот - по ГОСТ 32044.1-2012; сырой фосфор - по ГОСТ Р 51420-99.

Повторность опыта шестикратная, размещение делянок рендомизированное, площадь делянки 3,6 м $^{2}$, способ посева в опытах - рядовой (междурядья - 15 см), норма высева - 1,2 млн шт/га, глубина посева -5 см. Корневую подкормку микробиологическими удобрениями «Азотовит» и «Фосфатовит» проводили 2 раза, начиная с фазы бутонизации, с интервалом в десять дней. Для корневой подкормки применяли растворы рекомендованной концентрации и дозы из расчета 30 мл препарата на 10 л воды, норма расхода $-5 \pi / \mathrm{M}^{2}$.

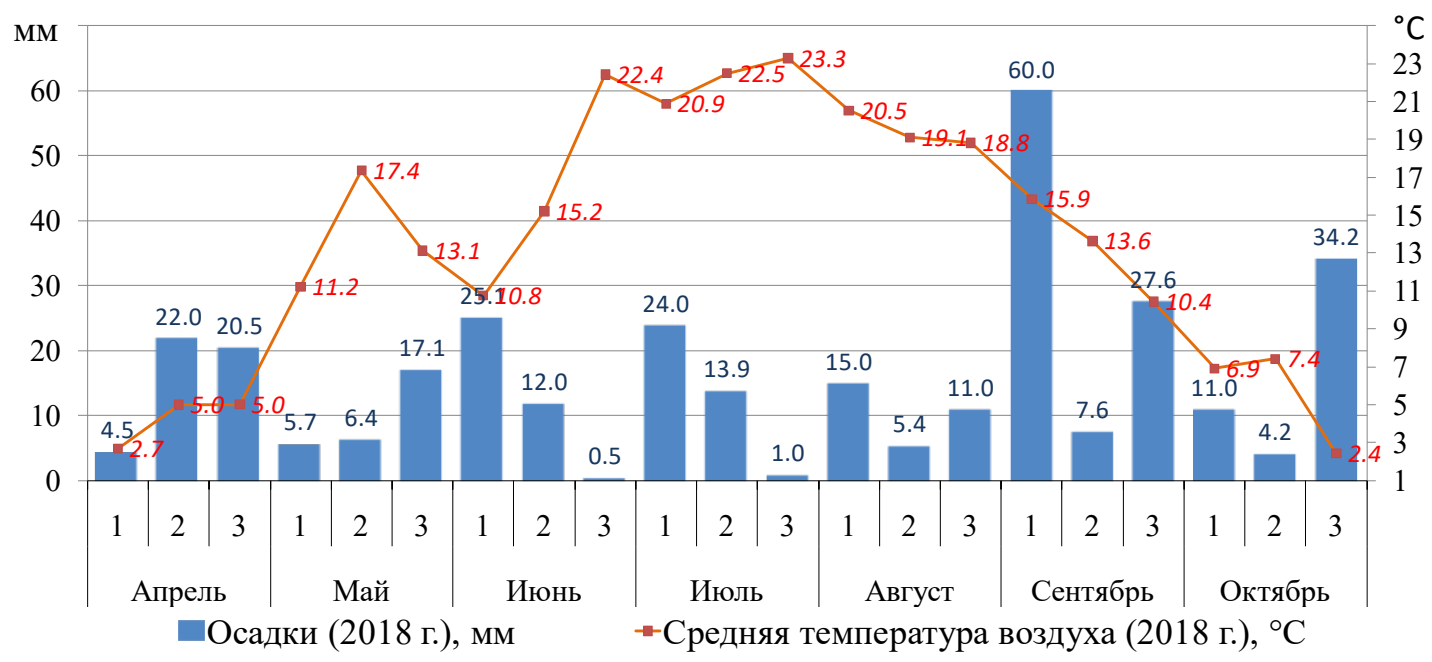

Рис. 1. Погодные условия вегетационного периода по декадам за 2018 г., мм

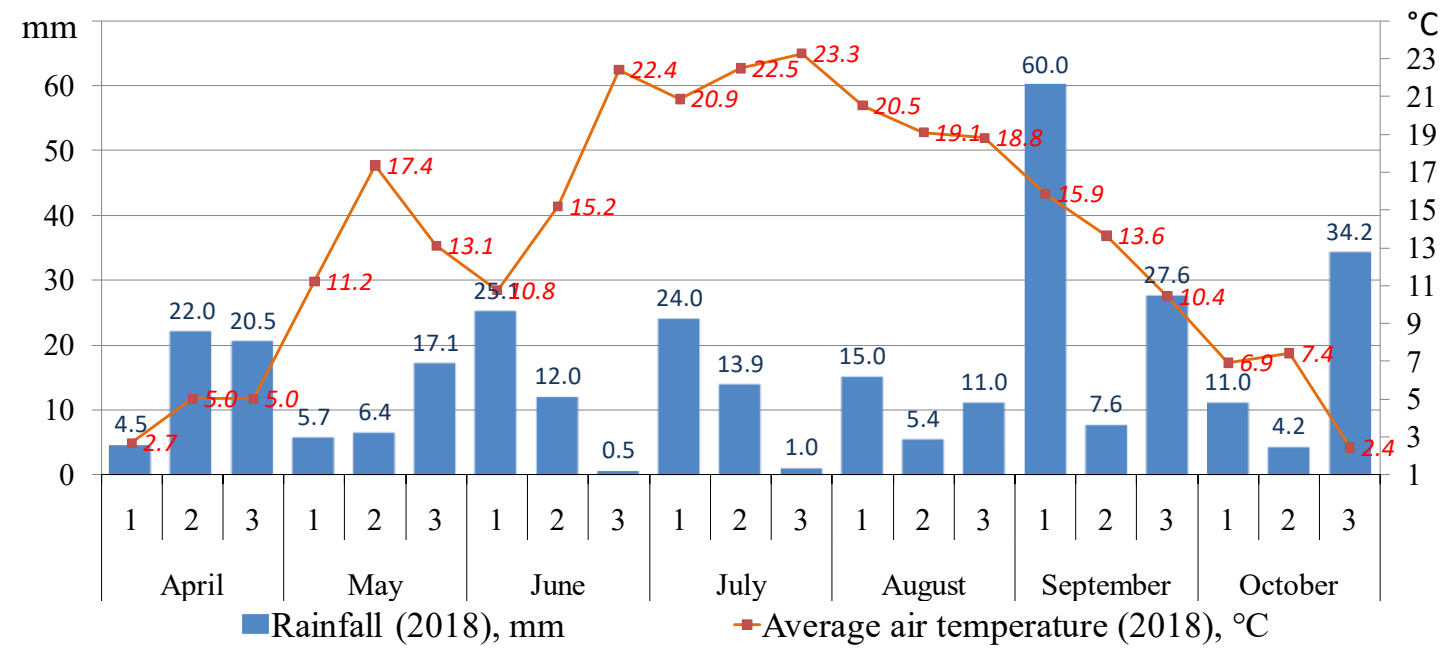

Fig. 1. Weather conditions of the growing season by decade for 2018, $\mathrm{mm}$ 


\section{Agrarian Bulletin of the Urals No. 02 (217), 2022}

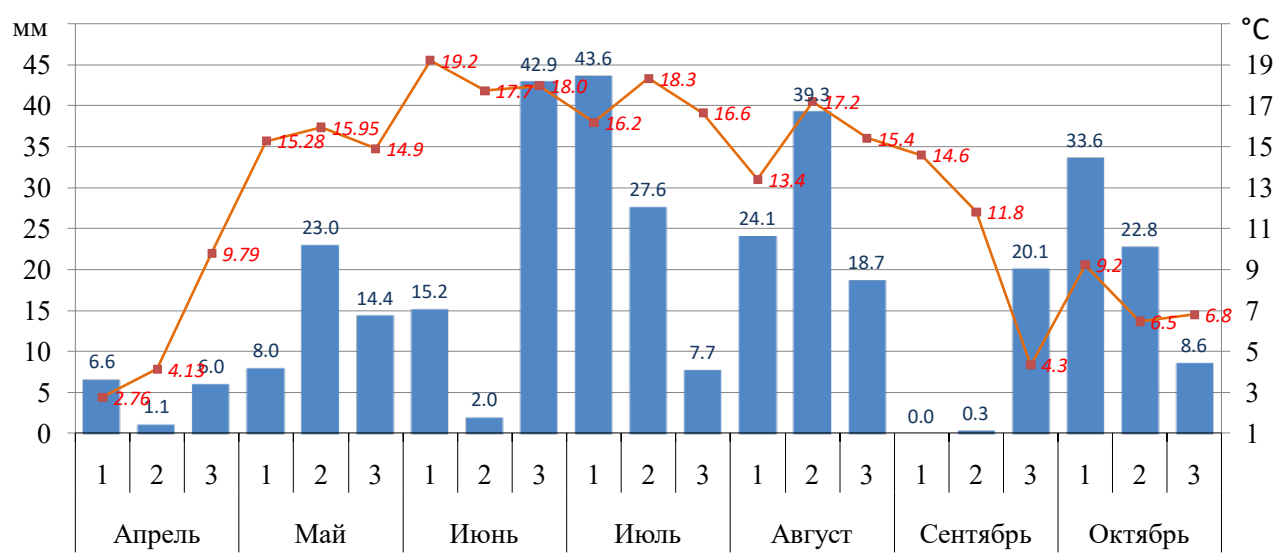

- Осадки (2019 г.), мм -Средняя температура воздуха (2019 г.), ${ }^{\circ} \mathrm{C}$ Рис. 2. Погодные условия вегетационного периода по декадам за 2019 г., мм

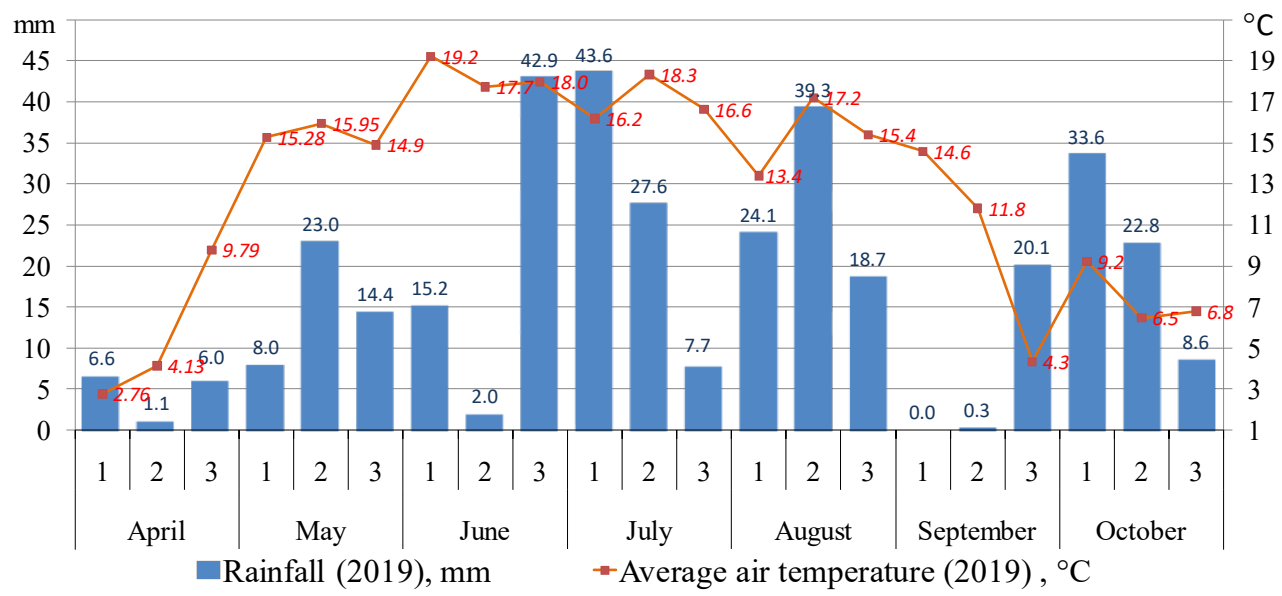

Fig. 2. Weather conditions of the growing season by decade for 2019, $\mathrm{mm}$

\section{Результаты (Results)}

В ходе проведения исследования в течение двух лет была выявлена эффективность применения микробиологических препаратов «Азотовит» и «Фосфатовит» в качестве корневой подкормки.

Погодные условия в Чувашской Республике в годы проведения исследования заметно отличались. Так, 2018 г. в начале вегетации оказался прохладным, однако впоследствии температура оказалась в среднем выше на 2-3 ${ }^{\circ} \mathrm{C}$ средних многолетних значений, осадков выпало недостаточно (рис. 1), дефицит влаги наблюдался в третьей декаде июня и в третьей декаде июля. Гидротермический коэффициент в 2018 г. составил 0,72, что указывает на засушливый год. Погодные условия оказали влияние на эффективность микробиологических удобрений, которая оказалась ниже, чем в 2019 г.

Вегетационный период 2019 г., наоборот, характеризовался умеренной температурой и избыточным количеством осадков (рис. 2), максимум которых пришелся на середину вегетации: третью декаду июня - начало июля, когда за две декады выпало полторы месячной нормы осадков. Показатель гидротермического коэффициента в 2019 году составил 1,31, что характерно для влажного года. До- статочное количество влаги и тепла в периоды подкормок обеспечили оптимальное развитие бактерий и их влияние на урожайность гороха.

Двукратная корневая подкормка микробиологическими удобрениями повлияла на процесс созревания сортов гороха, ускорив его. Быстрое созревание семян позволило приступить к уборке гороха в опытных вариантах на 3-6 дней раньше контроля, что немаловажно, особенно в неблагоприятные годы. До проведения подкормок в вариантах различий в наступлении фаз вегетации не наблюдалось. Впоследствии период от цветения до созревания оказался короче у обоих сортов в вариантах с применением подкормок, наибольшее влияние оказал препарат «Фосфатовит», в оба года исследований в данном варианте полная спелость наступила на 5-6 дней раньше контроля и на 2-3 дня раньше варианта с применением «Азотовита». В 2018 г. продолжительность вегетации составила в контроле у сорта Дударь 82 дня, у сорта Спартак - 80 дней, в вариантах с подкормкой «Азотовитом» - 78 и 77 дней, а с «Фосфатовитом» - 76 и 74 дня соответственно. 2019 г. отличался более продолжительным периодом от цветения до созревания семян. В целом в контроле созревание гороха наступило у сорта Ду- 
Таблица 1

\begin{tabular}{|c|c|c|c|c|}
\hline \multicolumn{5}{|c|}{ Средние значения состояния стеблестоя гороха за 2018-2019 гг. } \\
\hline Сорт & Вариант & $\begin{array}{c}\text { Полевая всхожесть, } \\
\text { \% }\end{array}$ & $\begin{array}{l}\text { Число растений } \\
\text { к уборке, шт//м² }\end{array}$ & $\begin{array}{l}\text { Сохранность } \\
\text { растений, \% }\end{array}$ \\
\hline \multirow{3}{*}{ Дударь } & Контроль & 78,4 & 78 & 83,3 \\
\hline & Подкормка «Азотовитом» & 78,2 & 84 & 88,6 \\
\hline & Подкормка «Фосфатовитом» & 76,9 & 80 & 85,9 \\
\hline \multirow{3}{*}{ Спартак } & Контроль & 78,1 & 79 & 83,5 \\
\hline & Подкормка «Азотовитом» & 76,7 & 81 & 87,6 \\
\hline & Подкормка «Фосфатовитом» & 76,2 & 77 & 84,3 \\
\hline \multicolumn{5}{|c|}{$\begin{array}{r}\text { Table } 1 \\
\text { Average values of the state of the pea stem for 2018-2019 }\end{array}$} \\
\hline Variety & Variant & $\begin{array}{l}\text { Field germination } \\
\text { rate, } \%\end{array}$ & $\begin{array}{c}\text { Number of plants } \\
\text { to be harvested, } \\
\text { pcs } / \mathrm{m}^{2}\end{array}$ & Plant safety, \% \\
\hline \multirow{3}{*}{ Dudar' } & Control & 78.4 & 78 & 83.3 \\
\hline & Nutrition with "Azotovit" & 78.2 & 84 & 88.6 \\
\hline & Nutrition with "Fosfatovit" & 76.9 & 80 & 85.9 \\
\hline \multirow{3}{*}{ Spartak } & Control & 78.1 & 79 & 83.5 \\
\hline & Nutrition with "Azotovit” & 76.7 & 81 & 87.6 \\
\hline & Nutrition with "Fosfatovit" & 76.2 & 77 & 84.3 \\
\hline
\end{tabular}

Таблица 2

Средние биометрические показатели растений гороха за 2018-2019 гг.

\begin{tabular}{|c|c|c|c|c|}
\hline \multirow{2}{*}{ Сорт } & \multirow{2}{*}{ Вариант } & \multicolumn{2}{|c|}{ Высота, см } & \multirow{2}{*}{$\begin{array}{c}\text { Количество междоузлий } \\
\text { на растении, шт. }\end{array}$} \\
\hline & & Растения & До первого боба & \\
\hline \multirow{3}{*}{ Дударь } & Контроль & 68,3 & 50,1 & 12 \\
\hline & Подкормка «Азотовитом» & 70,6 & 51,1 & 14 \\
\hline & Подкормка «Фосфатовитом» & 67,6 & 48,1 & 13 \\
\hline \multirow{3}{*}{ Спартак } & Контроль & 73,2 & 51,8 & 11 \\
\hline & Подкормка «Азотовитом» & 76,0 & 54,9 & 15 \\
\hline & Подкормка «Фосфатовитом» & 72,2 & 50,7 & 13 \\
\hline
\end{tabular}

Table 2

Average biometric indicators of pea plants for 2018-2019

\begin{tabular}{|c|c|c|c|c|}
\hline \multirow{3}{*}{ Variety } & Variant & $\begin{array}{c}\text { Plant height, } \\
\text { cm }\end{array}$ & $\begin{array}{c}\text { Height to the first } \\
\text { bean, cm }\end{array}$ & $\begin{array}{c}\text { Number of internodes, } \\
\text { pcs. }\end{array}$ \\
\hline \multirow{3}{*}{ Dudar, } & Control & 68.3 & 50.1 & 12 \\
\cline { 2 - 5 } & Nutrition with "Azotovit" & 70.6 & 51.1 & 14 \\
\cline { 2 - 5 } & Nutrition with "Fosfatovit" & 67.6 & 48.1 & 13 \\
\hline \multirow{3}{*}{ Spartak } & Control & 73.2 & 51.8 & 11 \\
\cline { 2 - 5 } & Nutrition with "Azotovit" & 76.0 & 54.9 & 15 \\
\cline { 2 - 5 } & Nutrition with "Fosfatovit" & 72.2 & 50.7 & 13 \\
\hline
\end{tabular}

дарь через 92 дня, у сорта Спартак - через 88 дней. Продолжительность вегетации в варианте с «Азотовитом» у сорта Дударь оказалась короче на 4 дня, у сорта Спартак - на 5 дней по сравнению с контролем. Растения гороха в вариантах, где применялась подкормка «Фосфатовитом», были самыми скороспелыми: в 2018 г. вегетация гороха завершилась за 76 дней у сорта Дударь и за 74 дня у сорта Спартак, в 2019 г. - соответственно за 84 и 81 день.

В среднем за два года исследований полевая всхожесть сортов гороха колебалась в пределах 76,2-78,4 \%. В 2018 г. всхожесть семян сорта Ду- дарь составила 82,5 \%, сорта Спартак - 83,3\%, в 2019 г. она оказалась ниже в среднем на $10 \%$ : гороха у сорта Дударь полевая всхожесть была 74,2 \%, у сорта Спартак - 72,9 \%.

В течение вегетации стеблестой гороха претерпел изменения, наблюдался небольшой выпад растений. Таким образом, сохранность растений к уборке составила в среднем от 83,3 до 88,6 \%. В 2018 г. у сорта Дударь к уборке сохранилось в среднем в контроле 83,4 \% взошедших растений, в варианте с «Азотовитом» - 90,6 \%, с «Фосфатовитом» $-86,5 \%$, у сорта Спартак в контроле сохра- 
нилось 82,5 \% растений, а применение подкормки «Азотовитом» увеличило количество сохранившихся к уборке растений на $6,9 \%$, «Фосфатовитом»на 3,3 \% по сравнению с контролем. Аналогичные данные были получены и в 2019 г.: у сорта Дударь в контроле сохранилось 83,2 \%, подкормка «Азотовитом» увеличила сохранность растений на 5,3 \%, а «Фосфатовитом» - на 2,6 \%. Сохранность растений сорта Спартак в варианте с контролем составила $84,5 \%$, в варианте с подкормками «Азотовитом»85,8 \%, «Фосфатовитом»-82,8\%. (таблица 1 ).

Микробиологические удобрения оказали влияние и на биометрические показатели растений гороха. В среднем за два года было отмечено увеличение высоты растений и высоты формирования первого боба, количества междоузлий на растениях при подкормке гороха «Азотовитом» у обоих сортов. При подкормке «Фосфатовитом», наоборот, данные показатели оказались наименьшими. Избыточное количество осадков в 2019 г. способствовало увеличению биометрических показателей гороха. Так, растения во всех вариантах оказались выше в среднем на 5-9 см, междоузлий сформировалось больше на 2-3. Растения сорта Спартак были более высокорослыми, в среднем их высота составила 72-76 см. Отмечено влияние «Азотовита» на высоту растений гороха и количество междоузлий: у сорта Дударь растения были выше на 2,3 см и сформировали на 2 междоузлия больше, у сорта Спартак - соответственно на 2,8 см и 4 междоузлия больше по сравнению с контролем.
Подкормка «Фосфатовитом», наоборот, уменьшила высоту растений гороха (таблица 2). Было отмечено влияние препарата «Фосфатовит» на повышение устойчивости сортов гороха к полеганию, особенно во влажный год. В контроле и в варианте с применением «Азотовита» устойчивость к полеганию составила 4,0-4,2 балла, а в варианте с «Фосфатовитом» - 4,3-4,5 балла, выше данный показатель оказался в 2018 г., так как избыток осадков в 2019 г. способствовал полеганию растений гороха.

Структура урожая анализировалась по следующим элементам: количеству растений на единице площади перед уборкой, количеству бобов на растении и семян в каждом бобе, массе 1000 семян. Проведенные исследования показали, что микробиологические удобрения повлияли на элементы структуры урожая у обоих сортов гороха. Так, у сорта Дударь подкормка «Азотовитом» способствовала увеличению количества бобов и семян с растения, что превысило контроль по данным показателям соответственно на 26,3 \% и 29,8 \%. Количество семян в каждом бобе и масса 1000 их штук практически не отличались от контроля. Подкормка «Фосфатовитом» сорта Дударь также способствовала увеличению показателей структуры урожая по сравнению с контролем. Подкормка данным препаратом увеличила количество бобов на растении на $12,2 \%$, количество семян с растения - на $10,4 \%$, также незначительно увеличилась и масса 1000 семян - до 168,6 г.

Таблица 3

Средние значения структуры урожая сортов гороха при проведении подкормок за 2018-2019 годы

\begin{tabular}{|c|c|c|c|c|c|c|}
\hline \multirow{3}{*}{ Сорт } & \multirow{2}{*}{ Вариант } & \multicolumn{2}{|c|}{ Количество, шт. } & \multicolumn{2}{c|}{ Масса, г } \\
\cline { 3 - 7 } & & $\begin{array}{c}\text { Бобов } \\
\text { настении }\end{array}$ & $\begin{array}{c}\text { Семян } \\
\text { с растения }\end{array}$ & $\begin{array}{c}\text { Семян } \\
\text { в одном бобе }\end{array}$ & $\begin{array}{c}\text { Семян } \\
\text { с растения }\end{array}$ & $\begin{array}{c}\mathbf{1 0 0 0} \\
\text { семян }\end{array}$ \\
\hline \multirow{3}{*}{ Дударь } & Контроль & 5,7 & 20,1 & 3,9 & 3,3 & 165,9 \\
\cline { 2 - 7 } & Подкормка «Азотовитом» & 7,2 & 26,1 & 4,0 & 4,4 & 166,6 \\
\cline { 2 - 7 } & Подкормка «Фосфатовитом» & 6,4 & 22,2 & 3,9 & 3,7 & 168,6 \\
\hline \multirow{3}{*}{ Спартак } & 5,1 & 17,8 & 3,7 & 3,4 & 189,3 \\
\cline { 2 - 7 } & Контроль & 6,0 & 18,9 & 3,5 & 3,7 & 193,8 \\
\cline { 2 - 7 } & Подкормка «Азотовитом» & 6,1 & 20,7 & 3,8 & 3,9 & 193,4 \\
\hline
\end{tabular}

Table 3

Average values of the crop structure of pea varieties after fertilizing for 2018-2019

\begin{tabular}{|c|c|c|c|c|c|c|}
\hline \multirow[b]{2}{*}{ Variety } & \multirow[b]{2}{*}{ Variant } & \multicolumn{3}{|c|}{ Number, pcs. } & \multicolumn{2}{|c|}{ Weight, $g$} \\
\hline & & $\begin{array}{l}\text { of beans } \\
\text { per plant }\end{array}$ & $\begin{array}{l}\text { of seeds } \\
\text { per plant }\end{array}$ & $\begin{array}{l}\text { of seeds } \\
\text { per bean }\end{array}$ & $\begin{array}{l}\text { of seeds } \\
\text { per plant }\end{array}$ & $\begin{array}{l}\text { of } 1000 \\
\text { seeds }\end{array}$ \\
\hline \multirow{3}{*}{ Dudar' } & Control & 5.7 & 20.1 & 3.9 & 3.3 & 165.9 \\
\hline & Nutrition with "Azotovit" & 7.2 & 26.1 & 4,0 & 4.4 & 166.6 \\
\hline & Nutrition with "Fosfatovit" & 6.4 & 22.2 & 3.9 & 3.7 & 168.6 \\
\hline \multirow{3}{*}{ Spartak } & Control & 5.1 & 17.8 & 3.7 & 3.4 & 189.3 \\
\hline & Nutrition with "Azotovit” & 6,0 & 18.9 & 3.5 & 3.7 & 193.8 \\
\hline & Nutrition with "Fosfatovit" & 6.1 & 20.7 & 3.8 & 3.9 & 192.4 \\
\hline
\end{tabular}




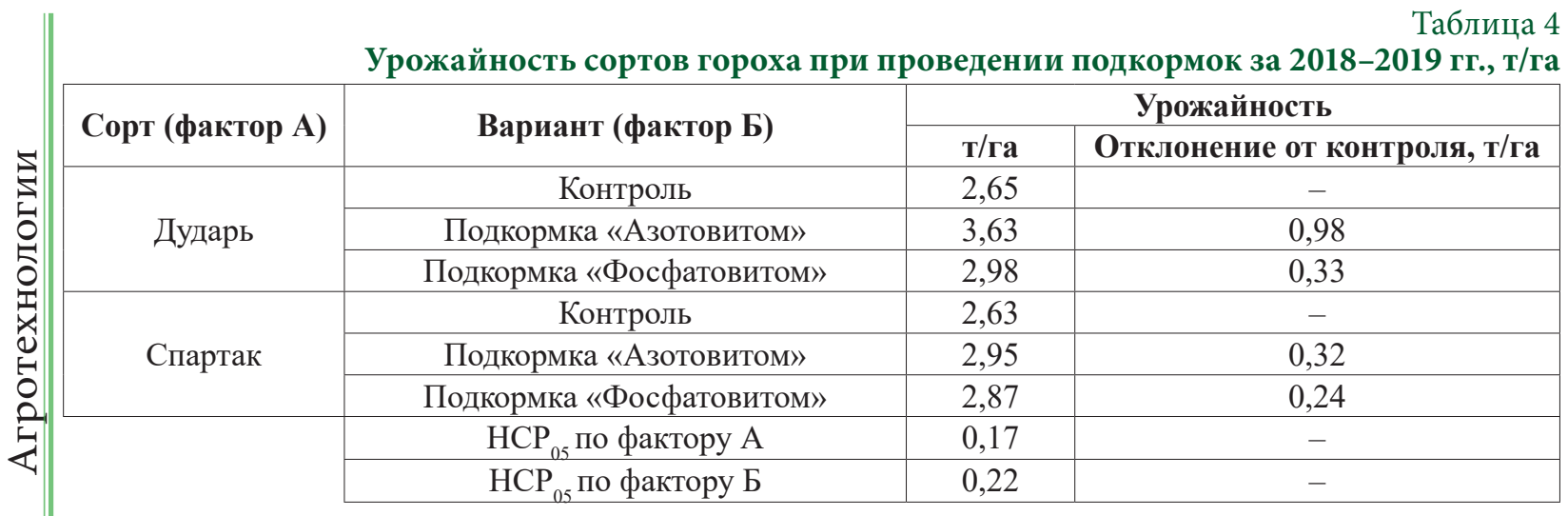

Table 4

Crop yield, of pea varieties after fertilizing for 2018-2019, t/ha

\begin{tabular}{|c|c|c|c|}
\hline \multirow{2}{*}{ Variety $($ factor $A)$} & \multirow{2}{*}{ Variant (factor B) } & \multicolumn{2}{|r|}{ Yield } \\
\hline & & $t / h a$ & Deviation from control, $t / h a$ \\
\hline \multirow{3}{*}{ Dudar' } & Control & 2.65 & - \\
\hline & Nutrition with "Azotovit" & 3.63 & 0.98 \\
\hline & Nutrition with "Fosfatovit" & 2.98 & 0.33 \\
\hline \multirow{5}{*}{ Spartak } & Control & 2.63 & - \\
\hline & Nutrition with Azotovit & 2.95 & 0.32 \\
\hline & Nutrition with "Fosfatovit" & 2.87 & 0.24 \\
\hline & $L S D_{05}($ factor $A)$ & 0.17 & - \\
\hline & $L S D_{05}($ factor $B)$ & 0.22 & - \\
\hline
\end{tabular}

У сорта Спартак наибольший эффект оказала подкормка «Фосфатовитом». В данном варианте наблюдалось увеличение количества бобов на растении на $19,6 \%$, семян с растения - на $16,3 \%$, массы 1000 семян - на 2,2 \% по сравнению с контролем. При подкормке «Азотовитом» получены более выполненные семена, масса 1000 штук была максимальной в опытах и составила 193,8 г (таблица 3).

Применение подкормок микробиологическими удобрениями «Азотовит» и «Фосфатовит» показало увеличение урожайности сортов гороха (таблица 4). Урожайность гороха в 2018 г. сорта Дударь в контроле составила 2,9 т/га, при подкормке «Азотовитом» - 3,71 т/га, что превысило контроль на $0,81 \mathrm{t} /$ га, а «Фосфатовитом» - 3,34 т/га, превысив контроль на 0,44 т/га. У сорта Спартак в контроле урожайность получена 2,42 т/га, подкормка «Азотовитом» повысила ее на 0,04 т/га, а «Фосфатовитом» - на 0,26 т/га по сравнению с контролем. В 2019 г. урожайность сорта Дударь в контроле составила 2,40 т/га, в варианте с подкормкой «Азотовитом» $-3,55$ т/га, что выше контроля на $1,15 \mathrm{~T} / \mathrm{ra}$; с подкормкой «Фосфатовитом» - 2,62 т/га.

Важно уделять внимание не только урожайности сельскохозяйственных культур, но и качеству получаемой продукции. Качественные показатели зерна гороха были проанализированы по содержанию сухого вещества, азота, сырого протеина, клетчатки, сырой золы, сырого жира и фосфора (таблица 5). «Азотовит» способствовал увеличению в зерне го- роха содержания азота и сырого протеина у обоих сортов. По сравнению с контролем у сорта Дударь содержание сырого протеина в зерне увеличилось на $2,83 \%$, у сорта Спартак - на $1,13 \%$, а азота соответственно на 0,41 и $0,21 \%$. У сорта Спартак также было отмечено увеличение содержания жира в данном варианте на $0,13 \%$ по сравнению с контролем. Подкормка «Фосфатовитом» увеличила в зерне содержание фосфора и сырого жира. Так, у сорта Дударь содержание жира между вариантами отличалось незначительно, а фосфора увеличилось по сравнению с контролем на $0,11 \%$; у сорта Спартак содержание жира в зерне повысилось на $0,09 \%$ а фосфора - на 0,11 \% по сравнению с контролем. В более сухой 2018 г. содержание в семенах гороха сухого вещества, сырого протеина и жира было выше, чем в 2019 г., хотя различия были незначительными. В целом корневые подкормки микробиологическими препаратами оказали влияние на качественные показатели зерна сортов гороха.

Поведенные исследования по изучению влияния корневых подкормок микробиологическими удобрениями «Азотовит» и «Фосфатовит» показали эффективность их применения при выращивании сортов гороха Дударь и Спартак на светло серых лесных почвах Чувашской Республики. Установлено, что подкормки оказали положительное влияние стеблестой гороха, увеличив сохранность растений к уборке. Подкормка «Фосфатовитом» повышала устойчивость к полеганию растений гороха, что до- 
Таблица 5

Результаты качественного анализа семян гороха, за 2018-2019 гг.

\begin{tabular}{|c|c|c|c|c|c|c|c|}
\hline $\begin{array}{c}\text { Показатели } \\
\text { качества семян }\end{array}$ & $\begin{array}{c}\text { Сухое } \\
\text { вещество, \% }\end{array}$ & Азот, \% & $\begin{array}{c}\text { Сырой } \\
\text { протеин, \% }\end{array}$ & $\begin{array}{c}\text { Клетчатка, } \\
\text { \% }\end{array}$ & $\begin{array}{l}\text { Сырая } \\
\text { зола, \% }\end{array}$ & $\begin{array}{l}\text { Сырой } \\
\text { жир, \% }\end{array}$ & $\begin{array}{c}\text { Фосфор, } \\
\text { Г/кг }\end{array}$ \\
\hline \multicolumn{8}{|c|}{ Дударь } \\
\hline Контроль & 95,3 & 3,1 & 19,21 & 5,45 & 3,15 & 1,50 & 0,28 \\
\hline $\begin{array}{c}\text { Подкормка } \\
\text { «Азотовитом» }\end{array}$ & 95,2 & 3,51 & 22,04 & 6,05 & 3,12 & 1,51 & 0,28 \\
\hline $\begin{array}{c}\text { Подкормка } \\
\text { «Фосфатовитом» }\end{array}$ & 95,3 & 3,23 & 20,67 & 5,59 & 3,07 & 1,53 & 0,39 \\
\hline \multicolumn{8}{|c|}{ Спартак } \\
\hline Контроль & 95,3 & 3,12 & 19,99 & 5,69 & 3,80 & 1,47 & 0,28 \\
\hline $\begin{array}{c}\text { Подкормка } \\
\text { «Азотовитом» }\end{array}$ & 95,5 & 3,33 & 21,12 & 5,80 & 3,51 & 1,60 & 0,28 \\
\hline $\begin{array}{c}\text { Подкормка } \\
\text { «Фосфатовитом» }\end{array}$ & 95,4 & 3,09 & 20,03 & 5,74 & 3,40 & 1,56 & 0,39 \\
\hline
\end{tabular}

Table 5

Results of qualitative analysis of pea seeds for 2018-2019

\begin{tabular}{|c|c|c|c|c|c|c|c|}
\hline $\begin{array}{c}\text { Seed quality } \\
\text { indicators }\end{array}$ & Solid $\underset{\%}{\text { matter, }}$ & $\begin{array}{c}\text { Nitrogen, } \\
\%\end{array}$ & $\begin{array}{c}\text { Crude } \\
\text { protein, \% }\end{array}$ & $\begin{array}{c}\text { Fiber, } \\
\%\end{array}$ & $\begin{array}{c}\text { Wet ash, } \\
\%\end{array}$ & $\begin{array}{c}\text { Wet oil, } \\
\%\end{array}$ & $\begin{array}{c}\text { Phosphorus, } \\
\text { g/kg }\end{array}$ \\
\hline \multicolumn{8}{|c|}{ Dudar' } \\
\hline Control & 95.3 & 3.1 & 19.21 & 5.45 & 3.15 & 1.50 & 0.28 \\
\hline $\begin{array}{l}\text { Nutrition with } \\
\text { "Azotovit" }\end{array}$ & 95.2 & 3.51 & 22.04 & 6.05 & 3.12 & 1.51 & 0.28 \\
\hline $\begin{array}{l}\text { Nutrition with } \\
\text { "Fosfatovit" }\end{array}$ & 95.32 & 3.23 & 20.67 & 5.59 & 3.07 & 1.53 & 0.39 \\
\hline \multicolumn{8}{|c|}{ Spartak } \\
\hline Control & 95.3 & 3,12 & 19.99 & 5.69 & 3.80 & 1.47 & 0.28 \\
\hline $\begin{array}{l}\text { Nutrition with } \\
\text { "Azotovit" }\end{array}$ & 95.5 & 3.33 & 21.12 & 5.80 & 3.51 & 1.60 & 0.28 \\
\hline $\begin{array}{l}\text { Nutrition with } \\
\text { "Fosfatovit" }\end{array}$ & 95.4 & 3.09 & 20.03 & 5.74 & 3.40 & 1.52 & 0.39 \\
\hline
\end{tabular}

статочно проявилось во влажный год. Была выявлена зависимость структуры урожая от подкормок микробиологическими удобрениями: наблюдалось увеличение количества бобов и семян на растениях, число образовавшихся семян в каждом бобе в вариантах с подкормками. Применение микроудобрений позволило получить более выполненные семена: масса 1000 семян сорта Спартак при подкормке «Азтовитом» составила 193,8 г, а «Фосфатовитом» - 192,4, у сорта Дударь - соответственно 166,6 г и 168,6 г, что превысило контрольный вариант. Оба микробиологических удобрения существенно повлияли на урожайность сортов гороха. Так, подкормка сорта Дударь «Азотовитом» увеличила урожайность на 37 \%, подкормка «Фосфатовитом» увеличила на 12,5 \% по сравнению с контролем, а у сорта Спартак - соответственно на 12,0\% и $9,1 \%$.

Обсуждение и выводы (Discussion and Conclusion)

Наблюдение за ростом и развитием растений гороха показало, что «Фосфатовит» позволяет ускорить процесс созревания.

Полученные результаты свидетельствует о влиянии изучаемых препаратов на формирование стеб- лестоя сортов гороха, в частности, на уменьшение выпада растений, а значит, повышения устойчивости растений к неблагоприятным факторам роста и развития.

Применение в качестве корневой подкормки способствует формированию менее высокорослых растений с более плотным стеблем, что предотвращает полегание гороха.

В среднем за два года применение микробиологических удобрений достоверно повышало урожайность сортов гороха. У обоих сортов эффективность от применения «Азотовита» оказалась выше, у сорта Дударь прибавка по отношению к контролю составила 0,98 т/га, к варианту с «Фосфатовитом» 0,33 т/га, у сорта Спартак - соответственно 0,32 и 0,24 т/га. Однако у сорта Спартак различия по урожайности между вариантами с микробиологическими препаратами оказались недостоверными.

Отмечено влияние микробиологических препаратов на качественные показатели полученного зерна гороха. Так, применение «Азотовита» способствовало увеличению содержания в зерне гороха сырого протеина и азота, а «Фосфатовита» - фосфора и сырого жира. 
Полученные результаты свидетельствуют о целесообразности проведения корневых подкормок на посевах гороха в условиях Чувашской Республики микробиологическими удобрениями с целью увеличения урожайности и содержания белка в зерне «Азотовитом», увеличения продуктивно- сти растений, ускорения созревания и повышения устойчивости к полеганию «Фосфатовитом» в фазу бутонизации - цветения. Для увеличения в зерне сырого протеина следует применять корневую подкорку «Азотовитом».

\section{Библиографический список}

1. Тычинская И. Л., Панарина В. И. Опыт применения микроудобрений серии «Интермаг профи» и биостимулятора «Биостим» на различных сельскохозяйственных культурах (обзор) // Вестник аграрной науки. 2020. № 6 (87). С. 45-54.

2. Елисеев И. П., Елисеева Л. В. Биологизация земледелия - элемент ресурсосбережения // Актуальные направления технологического, экономического и экологического развития сельского хозяйства: материалы международной научно-практической конференции. Екатеринбург, 2017. С. 422-426.

3. Stamenković S., Karabegović I., Lazić M., et al. Microbial fertilizers: A comprehensive review of current findings and future perspectives // Spanish Journal of Agricultural Research. 2018. Vol. 16. No. 1. Article number e09R01. 4. Елисеева Л. В., Каюкова О. В., Елисеев И. П. Влияние подкормок микробиологическими удобрениями на урожай и качество семян // Вестник Курской государственной сельскохозяйственной академии. 2019. № 2. С. 33-38.

5. Ложкин А. Г., Елисеева Л. В., Филиппова С. В. Влияние способов посева и микроудобрений на продуктивность сои // Вестник Ульяновской государственной сельскохозяйственной академии. 2020. № 1 (49). С. 38-44. 6. Петровский А. С.,. Каракотов С. Д Микробиологические препараты в растениеводстве. Альтернатива или партнерство? // Защита и карантин растений. 2017. № 2. С. 14-18.

7. Остробородова Н. И. Бактериальные удобрения в технологии возделывания кормовых бобов // Инновационные технологии в растениеводстве и экологии: материалы Международной научно-практической конференции, посвященной 80-летию со дня рождения ученого-микробиолога-агроэколога, заслуженного работника высшей школы России, заслуженного деятеля науки Северной Осетии, доктора сельскохозяйственных наук, профессора Александра Тимофеевича Фарниева, Владикавказ, 2017. С. 239-240.

8. Каримова Е. Р., Худайгулов Г. Г. Изучение влияния биопрепарата на основе клубеньковых бактерий Rhizobium lupini на бобовые и злаковые культуры // Вестник Южно-Уральского государственного университета. Серия: Пищевые и биотехнологии. 2018. Т. 6. № 2. С. 52-57.

9. Popov V., Serekpaev N., Stybaev G. Adaptive technology of environmentally - friendly production of legumes in the dry steppe zones // Journal of Central European Agriculture. 2017. Vol. 18. No. 1. Pp. 73-94.

10. Полухина М. Г., Зубарева К. Ю. Направления биологизации возделывания гороха // 100-летие кафедры растениеводства, кормопроизводства и агротехнологий: итоги и перспективы инновационного развития: Юбилейный сборник научных трудов: материалы международной научно-практической конференции факультета агрономии, агрохимии и экологии, Воронеж, 2019. С. 297-300.

11. Tiranov A. B., Tiranova L. V. The effect of azotovit and fosfatovit on the yield of vetch // IOP Conference Series: Earth and Environmental Science. Veliky Novgorod, 2020. Article number 012149.

12. Любек Н. И., Седяков М. В. Влияние микробиологических удобрений «Азотовит» и «Фосфатовит» на хозяйственно-ценные признаки сорта ярового ячменя Ленинградский // Международный научный сельскохозяйственный журнал. 2018. № 1-4. С. 18-22.

13. Koryagin Y., Kulikova E., Koryagina N., Kuznetsov A. Agroecological evaluation of application the microbiological fertilizers in lentil cultivation technology // Scientific papers. Series A-Agronomy. 2020. Vol. 63. No. 1. Pp. 361-365.

14. Корягин Ю. В.,. Корягина Н. В, Куликова Е. Г., Галиуллин А. А. Качество получаемой продукции при использовании микробиологических удобрений в технологии возделывания сельскохозяйственных культур // Сурский вестник. 2020. № 3 (11). С. 38-43.

15. «Азотовит» и «Фосфатовит» - природа может больше // АгроСнабФорум. 2017. № 7 (155). С. $56-57$.

16. Государственный реестр селекционных достижений [Электронный ресурc]. URL: https://reestr.gossortrf. ru/sorts/9463911 (дата обращения: 10.05.2021).

17. Доспехов Б. А. Методика полевого опыта (с основами статистической обработки результатов исследований). 5-е изд., доп. и перераб. Москва: Агропромиздат, 1985. 351 с.

\section{Об авторах:}

Надежда Николаевна Михайлова ${ }^{1}$, аспирант, ассистент кафедры земледелия, растениеводства, селекции и семеноводства, ORCID 0000-0003-3245-3656, AuthorID 1056941; +7 93739403 11, cool.gordeeva@list.ru 
Людмила Валерьевна Елисеева ${ }^{1}$, кандидат сельскохозяйственных наук, доцент кафедры земледелия, растениеводства, селекции и семеноводства, ORCID 0000-0002-2414-5947, AuthorID 318037; + 7 937 015-95-02, ludmilaval@yandex.ru

Иван Петрович Елисеев ${ }^{1}$, кандидат сельскохозяйственных наук, доцент кафедры земледелия, растениеводства, селекции и семеноводства, ORCID 0000-0002-0266-5589, AuthorID 607375; +7 937 951-11-95, ipelis21@rambler.ru

${ }^{1}$ Чувашский государственный агарный университет, Чебоксары, Россия

\title{
Application of fertilizing with microbiological preparations "Azotovit" and "Fosfatovit" on pea crops
}

\author{
N. N. Mikhaylova ${ }^{1 凶}$, L. V. Eliseeva ${ }^{1}$, I. P. Eliseev ${ }^{1}$ \\ ${ }^{1}$ Chuvash State Agrarian University, Cheboksary, Russia \\ ${ }^{\otimes}$ E-mail: cool.gordeeva@list.ru
}

\begin{abstract}
In today's world, focusing on production of environmentally friendly products: the use of toxic chemicals severely affects not only the environment but also on human health. In this regard, the production of an alternative to pesticides - biological products - is growing. The use of microbiological fertilizers improves soil fertility, increases crop yields. The purpose of the work is to study the effect of fertilizing with microbiological fertilizers "Azotovit" and "Fosfatovit" on the productivity of pea varieties. The scientific novelty of the work is that in the first, in the conditions of the Chuvash Republic in the training and production research center "Studencheskiy" on light gray forest soil, there was a study of the effect of microbiological fertilizers on the productivity of pea varieties. Methods records and observations were carried out according to the generally accepted method of conducting field experiments. Results. A study conducted during 2018-2019 in the Chuvash Republic revealed a positive effect of fertilizing with microbiological fertilizers on the Dudar' and Spartak pea varieties. Changes in the height of plants, an increase in their safety, an increase in the indicators of the structure of the yield and the yield of pea varieties were noted. Thus, fertilizing peas of the Spartak variety with "Azotovit" increased the height of plants by $4 \%$, while feeding with "Fosfatovit", no changes were observed in this indicator. The use of "Azotovit" on the Dudar' variety increased plant safety by $5.3 \%$, and "Fosfatovit" - by $2.6 \%$. The analysis of the elements of the yield structure showed that feeding with microbiological fertilizers increased the number of beans per plant, seeds in one bean, as well as the mass of seeds per plant and 1000 pieces. A significant increase in yield was found when feeding pea varieties. Thus, the use of "Azotovit" on crops of the Dudar' variety increased the yield by $37 \%$, and "Fosfatovit" - by $12.5 \%$; in variants with the Spartak variety, fertilizing with "Azotovit" increased the yield by $12.0 \%$, and fertilizing with "Fosfatovit" by $9.1 \%$.
\end{abstract}

Keywords: peas, microbiological fertilizers, Azotovit, Fosfatovit, productivity, nutrition, crop structure, yield.

For citation: Mikhaylova N. N., Eliseeva L. V., Eliseev I. P. Primenenie podkormki mikrobiologicheskimi preparatami "Azotovit" i "Fosfatovit" na posevakh gorokha [Application of fertilizing with microbiological preparations "Azotovit" and "Fosfatovit" on pea crops] // Agrarian Bulletin of the Urals. 2022. No. 02 (217). Pp. 12-22. DOI: 10.32417/1997-4868-2022-217-02-12-22. (In Russian.)

Date of paper submission: 13.07.2021, date of review: 03.09.2021, date of acceptance: 30.09.2021.

\section{References}

1. Tychinskaya I. L., Panarina V. I. Opyt primeneniya mikroudobreniy serii "Intermag profi" i biostimulyatora "Biostim" na razlichnykh sel'skokhozyaystvennykh kul'turakh (obzor) [Experience in using microfertilizers of the intermagprofi series and the biostimulatorbiostim on various agricultural crops(review)] // Bulletin of agrarian science. 2020. No. 6 (87). Pp. 45-54. DOI: 10.17238/issn2587-666X.2020.6.45. (In Russian.)

2. Eliseev I. P., Eliseeva L.V. Biologizatsiya zemledeliya - element resursosberezheniya [Agricultural biologization - a resource element] // Aktual'nye napravleniya tekhnologicheskogo, ekonomicheskogo i ekologicheskogo razvitiya sel'skogo khozyaystva: materialy mezhdunarodnoy nauchno-prakticheskoy konferentsii. Ekaterinburg, 2017. Pp. 422-426. (In Russian.)

3. Stamenković S., Karabegović I., Lazić M., et al. Microbial fertilizers: A comprehensive review of current findings and future perspectives // Spanish Journal of Agricultural Research. 2018. Vol. 16. No. 1. Article number e09R01. 
4. Eliseeva L. V., Kayukova O. V., Eliseev I. P. Vliyanie podkormok mikrobiologicheskimi udobreniyami na urozhay i kachestvo semyan [The effect of microbiological dressing of fertilizers on yield and quality of soybean seeds] // Vestnik Kurskoy gosudarstvennoy sel'skokhozyaystvennoy akademii. 2019. No. 2. Pp. 33-38. (In Russian.)

5. Lozhkin A. G., Eliseeva L. V., Filippova S. V. Vliyanie sposobov poseva i mikroudobreniy na produktivnost' soi [Influence of seeding methods and micronutrients on the productivity of soybean] // Vestnik of Ulyanovsk State Agricultural Academy. 2020. No. 1 (49). Pp. 38-44. DOI: 10.18286/1816-4501-2020-1-38-44. (In Russian.) 6. Petrovskiy A. S., Karakotov S. D. Mikrobiologicheskie preparaty v rastenievodstve. Al'ternativa ili partnerstvo? [Microbiological preparations in crop production. Alternative or partnership?] // Zashchita i karantin rasteniy. 2017. No. 2. Pp. 14-18. (In Russian.)

7. Ostroborodova N. I. Bakterial'nye udobreniya v tekhnologii vozdelyvaniya kormovykh bobov [Bacterial fertilizers in the technology of fodder bean cultivation] // Innovatsionnye tekhnologii v rastenievodstve i ekologii: materialy Mezhdunarodnoy nauchno-prakticheskoy konferentsii, posvyashchennoy 80-letiyu so dnya rozhdeniya uchenogo-mikrobiologa-agroekologa, zasluzhennogo rabotnika vysshey shkoly Rossii, zasluzhennogo deyatelya nauki Severnoy Osetii, doktora sel'skokhozyaystvennykh nauk, professora Aleksandra Timofeevicha Farnieva. Vladikavkaz, 2017. Pp. 239-240. (In Russian.)

8. Karimova E. R., Khudaygulov G. G. Izuchenie vliyaniya biopreparata na osnove kluben'kovykh bakteriy Rhizobium lupini na bobovye i zlakovye kul'tury [Study of the effect of the biological product based on rhizobium lupini nodule bacteria on legumes and cereals] // Vestnik Yuzhno-Ural'skogo gosudarstvennogo universiteta. Seriya: Pishchevye i biotekhnologii. 2018. T. 6. No. 2. Pp. 52-57. DOI: 10.14529/food180207. (In Russian.)

9. Popov V., Serekpaev N., Stybaev G. Adaptive technology of environmentally - friendly production of legumes in the dry steppe zones // Journal of Central European Agriculture. 2017. Vol. 18. No. 1. Pp. 73-94.

10. Polukhina M. G., Zubareva K. Yu. Napravleniya biologizatsii vozdelyvaniya gorokha [Areas of biological cultivation of peas] // 100-letie kafedry rastenievodstva, kormoproizvodstva i agrotekhnologiy: itogi i perspektivy innovatsionnogo razvitiya: Yubileynyy sbornik nauchnykh trudov: materialy mezhdunarodnoy nauchno-prakticheskoy konferentsii fakul'teta agronomii, agrokhimii i ekologii. Voronezh, 2019. Pp. 297-300. (In Russian.)

11. Tiranov A. B., Tiranova L. V. The effect of azotovit and fosfatovit on the yield of vetch // IOP Conference Series: Earth and Environmental Science. Veliky Novgorod, 2020. Article number 012149.

12. Lyubek N. I., Sedyakov M. V. Vliyanie mikrobiologicheskikh udobreniy "Azotovit" i "Fosfatovit" nakhozyaystvenno-tsennye priznaki sortayarovogo yachmenya Leningradskiy [The influence of microbiological fertilizers "Azotovit" and "Phosphatovit" on the economically valuable traits of spring barley leningradsky] // International Agricultural Journal. 2018. No. 1-4. Pp. 18-22. (In Russian.)

13. Koryagin Y., Kulikova E., Koryagina N., Kuznetsov A. Agroecological evaluation of application the microbiological fertilizers in lentil cultivation technology // Scientific papers. Series A-Agronomy. 2020. Vol. 63. No. 1. Pp. 361-365.

14. Koryagin Yu. V., Koryagina N. V, Kulikova E. G., Galiullin A. A. Kachestvo poluchaemoy produktsii pri ispol'zovanii mikrobiologicheskikh udobreniy v tekhnologii vozdelyvaniya sel'skokhozyaystvennykh kul'tur [The quality of the products obtained when using microbiological fertilizers in the technology] // Surskiy vestnik. 2020. No. 3 (11). Pp. 38-43. (In Russian.)

15. "Azotovit" i "Fosfatovi" - priroda mozhet bol'she ["Azotovit" and "Phosphatovit" - nature can do more] // AgroSnabForum. 2017. No. 7 (155). Pp. 56-57. (In Russian.)

16. Gosudarstvennyy reestr selektsionnykh dostizheniy [State Register of selection achievements [e-resource]. URL: https://reestr.gossortrf.ru/sorts/9463911 (date of reference: 10.05.2021). (In Russian.)

17. Dospekhov B. A. Metodika polevogo opyta (s osnovami statisticheskoy obrabotki rezul'tatov issledovaniy) [Methodology of field experience (with the basics of statistical processing of research results)]. Moscow: Agropromizdat, 1985. 351 p. (In Russian.)

\section{Authors'information:}

Nadezhda N. Mikhaylova ${ }^{1}$, postgraduate, assistant of the department of agriculture, plant growing, breeding and seed production, ORCID 0000-0003-3245-3656, AuthorID 1056941; +7 93739403 11, cool.gordeeva@list.ru

Lyudmila V. Eliseeva ${ }^{1}$, candidate of agricultural sciences, associate professor of the department of agriculture, plant growing, breeding and seed production, ORCID 0000-0002-2414-5947, AuthorID 318037; +7 937 015-95-02, ludmilaval@yandex.ru

Ivan P. Eliseev ${ }^{1}$, candidate of agricultural sciences, associate professor of the department of agriculture, plant growing, breeding and seed production, ORCID 0000-0002-0266-5589, AuthorID 607375; + 7 937 951-11-95, ipelis21@rambler.ru

${ }^{1}$ Chuvash State Agrarian University, Cheboksary, Russia 